\title{
A Memorial Day Lament for Capt. Wilfred Owen, Sgt. Joyce Kilmer, And all the Others Who Shouldn't Have Died in Foolish Wars
}

\author{
Walter G. Moss* \\ Professor Emeritus of History, Eastern Michigan University USA
}

*Corresponding Author: Walter G. Moss, Professor Emeritus of History, Eastern Michigan University USA

Since Memorial Day is a holiday to honor U. S. veterans who died in war, it is fitting to honor one, the poet Sgt. Joyce Kilmer. And since even more English families lost loved ones in that war (WWI), it is also proper to memorialize the English poet Captain Wilfred Owen.

A main problem with many war accounts is their failure to evoke the full tragedy that people suffered. As one historian has written, "Among the major [European] combatants, it is not an exaggeration to suggest that every family was in mourning: most for a relative-a father, a son, a brother, a husband-others for a friend, a colleague, a lover, a companion."

Ian McEwan's novel Black Dogs (1993) captures well the scope of such tragedy when he writes of his main character: "He was struck by the recently concluded war [World War II in Europe] not as a historical, geopolitical fact but as a multiplicity, a near-infinity of private sorrows, as a boundless grief minutely subdivided without diminishment among individuals who covered the continent like dust.... For the first time he sensed the scale of the catastrophe in terms of feeling; all those unique and solitary deaths, all that consequent sorrow, unique and solitary too, which had no place in conferences, headlines, history, and which had quietly retired to houses, kitchens, unshared beds, and anguished memories."

At least, however, the war McEwan writes of (WWII) was fought against a major evil, Adolf Hitler's Nazi regime, and such a fight was more justifiable than WWI. Although Kaiser Wilhelm II's erratic, insecure, and belligerent personality shares part of the blame for the war's start in the summer of 1914, none of the other European leaders had done all they might to prevent the conflict from occurring. They had all valued security, prestige, influence, and allies more than peace, and they had all failed to imagine the full scale of the tragedy they were about to unleash.

Recalling on this Memorial Day the lives of just two soldiers who died, Owen and Kilmer, can help at least open the symbolic gates of that massive WWI millions-of-bodies cemetery.

Wilfred Owen was born in 1893 in Shropshire County, which sits east of Wales. The youth of this shy, sensitive boy was spent in this county, especially in two of its small towns where he received most of his education, Shrewsbury and Birkenhead. He was the oldest of four children, and his father worked for the railway, serving for a time as a stationmaster of a small station. Paul Fussell, in his widely-praised The Great War and Modern Memory(1975), tells us that the dad's "salary sufficed to maintain the family in genteel poverty," and that as a boy Wilfred was "closer to his mother," who was "pious, puritanical, and strong-willed." The poet C. Day Lewis tells us that "his relationship with his mother ... remained the closest one in his short life."

Although she encouraged him to pursue a religious vocation, he was from a young age determined to be a poet, a choice his father frowned upon, insisting poetry would not provide an adequate living. Although attending a few university classes in Reading, Wilfred could not afford a full higher education. Instead, from 1911 to 1913 he served as a lay assistant to the Vicar of Dunsden (near Reading). In that 
capacity, he sometimes visited poor families and was disappointed that the Anglican Church could not provide more aid to the needy.

Later in 1913 he went to Bordeaux, France, first to teach English in a Berlitz School, and then in 1914 to act as a tutor in a French family. He did not return to England until September, 1915, at age 22, thirteen months after WWI had begun. A month later he enlisted in the Army, and the following June he received his officer's commission. Not until January 1917 was he sent to France, specifically to the trenches of the Somme battlefield. There, for more than four months in the previous year, the British had suffered 420,000 casualties, including 125,000 deaths. If German and French casualties are added, more than one million men were killed or wounded on that battlefield from July to November.

The exact nature of Owen's private life from 1914 to 1916 is disputed, with some sources suggesting or stating he was gay. More important for our purposes, however, is his development as a man and a poet. The poet Day notes that in looking at Owen's poetry of 1917 and 1918 he found himself "more and more amazed at the suddenness of his development from a very minor poet to something altogether larger. It was as if, during the weeks of his first tour of duty in the trenches, he came of age emotionally and spiritually."

Another poet and soldier, Edmund Blunden, in his "Memoir" of Owen, quotes letters Owen wrote home. In mid-January 1917 he writes of moving "along a flooded trench. After that we came to where the trenches had been blown flat out. ... It was of course dark, too dark, and the ground was . . . an octopus of sucking clay, 3, 4, and 5 feet deep, relieved only by craters full of water. Men have been known to drown in them. Many stuck in the mud and only got on by leaving their waders, equipment, and in some cases their clothes. High explosives were dropping all around, and machine-guns spluttered every few minutes. But it was so dark that even the German flares did not reveal us."

Blunden mentions that "the winter of 1916-1917 will long be remembered for its scarcely tolerable cold,." and he quotes an Owen letter in later January: "In this place my platoon had no dug-outs, but had to lie in the snow under the deadly wind. By day it was impossible to stand up, or even crawl about, because we were behind only a little ridge screening us from the Boche's [German's] periscope?"

Fussell sums up Owen's frontline experiences in 1917 and 1918 this way: "In the less than two years left to him, the emotions that dominated were horror, outrage, and pity: horror at what he saw at the front; outrage at the inability of the civilian world-- especially the church--to understand what was going on; pity for the poor, dumb, helpless, good-looking boys victimized by it all. He was in and out of the line half a dozen times during the first four months of 1917."

Then in late April 1917 Owen wrote, "For twelve days we lay in holes, where at any moment a shell might put us out. I think the worst incident was one wet night when we lay up against a railway embankment. A big shell lit on the top of the bank, just 2 yards from my head. Before I awoke, I was blown in the air right away from the bank! I passed most of the following days in a railway cutting, in a hole just big enough to lie in, and covered with corrugated iron. My brother officer of B Coy., 2nd Lt. G., lay opposite in a similar hole. But he was covered with earth, and no relief will ever relieve him." Finally, Owen was evacuated and a doctor forbade him to go back into action and diagnosed his condition as neurasthenia.

For the next year Owen found himself in various hospitals or on duty back in England. In a hospital near Edinburgh he met two other English officers and war poets, Siegfried Sassoon and Robert Graves. The older Sassoon, from a wealthy Jewish family, had been wounded in combat and arrived at the hospital after Owen, but not before writing a famous protest against the war, a protest that was read in the House of Commons. It states: "I am making this statement as an act of willful defiance of military authority, because I believe that the War is being deliberately prolonged by those who have the power to end it. I am a soldier, convinced that I am acting on behalf of soldiers. I believe that this War, upon which I entered as a war of defence and liberation, has now become a war of aggression and conquest. ... I have seen and endured the sufferings of the troops, and I can no longer be a party to prolonging those sufferings for ends which I believe to be evil and unjust." Owen admired and was influenced by the older officer and poet, but even before meeting him had expressed his own criticism of the war.

While still at the hospital Owen wrote a first draft of one of his most famous poems, "Dulce et Decorum Est."

Bent double, like old beggars under sacks, 
Knock-kneed, coughing like hags, we cursed through sludge,

Till on the haunting flares we turned our backs,

And towards our distant rest began to trudge.

Men marched asleep. Many had lost their boots,

But limped on, blood-shod. All went lame; all blind;

Drunk with fatigue; deaf even to the hoots

Of gas-shells dropping softly behind.

Gas! GAS! Quick, boys!- An ecstasy of fumbling

Fitting the clumsy helmets just in time,

But someone still was yelling out and stumbling

And flound'ring like a man in fire or lime.-

Dim through the misty panes and thick green light,

As under a green sea, I saw him drowning.

In all my dreams before my helpless sight,

He plunges at me, guttering, choking, drowning.

If in some smothering dreams, you too could pace

Behind the wagon that we flung him in,

And watch the white eyes writhing in his face,

His hanging face, like a devil's sick of sin;

If you could hear, at every jolt, the blood

Come gargling from the froth-corrupted lungs,

Obscene as cancer, bitter as the cud

Of vile, incurable sores on innocent tongues,-

My friend, you would not tell with such high zest

To children ardent for some desperate glory,

The old Lie: Dulce et decorum est

Pro patria mori [It is sweet and fitting to die for one's country].

Before Owen left the hospital he became friendly with a Mrs. Mary Gray, who had an infant daughter. Blunden quotes Gray at length on what a fine man Owen was. She speaks of his "sensitiveness, his sympathy," his "wonderful tenderness," and adds that the bond which drew them "together was an intense pity for suffering humanity - a need to alleviate it, wherever possible, and an inability to shirk the sharing of it, even when this seemed useless."

Despite Owen's criticism of the war, Fussell tells us that he was anxious "to return to the front although he knew he was going to be killed. Having seen the suffering of the men: he had to be near them. As the voice of inarticulate boys, he had to testify on their behalf." He returned to France in September, 1918. "In an attack during the first days of October he won the Military Cross. In another attack . . . on November 4, he was machine-gunned to death." One week later the war ended, and an hour after it did, with bells still ringing in celebration, his parents received the telegram informing them of their son's death.

Of the impact of Owen's poetry, most of which was published after his battlefield death, fellow poet and WWI soldier Day wrote that thirty-five years after first reading it, he realized "how much it has become part of my life and thinking." In addition, while praising other WWI soldier-poets, Day stated "It is 
Owen, I believe, whose poetry came home deepest to my own generation, so that we could never again think of war as anything but a vile, if necessary, evil."

Entering the war later, but dying earlier than Owen was the American poet Kilmer. For him we have two excellent online sources. The first is a memoir by his mother, which also contains some of his poems and letters. The second is a memoir by his friend Robert Cortes Holliday, who was a fellow writer and editor.

Kilmer was born in New Jersey in 1886 to a well-off family--his father invented Johnson \& Johnson's Baby Powder. Like Owen, Joyce was close to his mother, and her memoir details that relationship and all the honors and accomplishments of her son up through and beyond his college years at Rutgers and Columbia. He graduated from the latter university in May 1908, and the next month married Aline Murray. She was the step-daughter of a Harper's Magazine editor and herself a poet. Before Joyce went off to war in 1917, the couple had five children, but their oldest daughter, Rose, died shortly before he left. In 1913, she had been stricken with infantile paralysis, an incident that convinced Joyce and Aline to convert to Catholicism. For the rest of his short life his new religion would be very important to him, and by the time he was killed in 1918, he was considered the leading U. S. Catholic poet.

The same year as his conversion saw the publication of his most famous poem, "Trees."

I think that I shall never see

A poem lovely as a tree.

A tree whose hungry mouth is prest

Against the earth's sweet flowing breast;

A tree that looks at God all day,

And lifts her leafy arms to pray;

A tree that may in Summer wear

A nest of robins in her hair;

Upon whose bosom snow has lain;

Who intimately lives with rain.

Poems are made by fools like me,

But only God can make a tree.

The poem is typical of his simple, straightforward style, as well as his religious sentiments. And although a popular poem with the general reading public, critics do not rank it or him with the best American poems and poets. Nevertheless, his friend Holliday and others depict him as a good and decent man who possessed a fine sense of humor and loved life and his family. Just a few examples from Holliday: "His smile, never far away, when it came, was winning, charming." "I really doubt very much whether anybody ever enjoyed food more than Kilmer."

Although several books of his poems appeared during his lifetime, like most poets he could not support his growing family on his poetry alone. Thus, he worked at various jobs, mainly in publishing, editing, and writing reviews and essays, in and around New York city. He also often lectured, at which he was very good.

After a brief infatuation with socialism as a young married man, his enthusiasms were much more literary (e.g., for Walter Scott, Charles Dickens, and W. B. Yeats) than political. When WWI began, he was upset at the German invasion of neutral Belgium, but until May 1915, when a German U-boat sank the British passenger liner Lusitania, he was not anti-German. But the sinking, with the loss of 1,198 
lives, including 128 Americans, turned him against the Kaiser's aggression. His poem of that time, "The White Ships and the Red," reflects his abhorrence at the Lusitania's sinking with its loss of civilian lives, including women and children, and his growing belief that the war was a battle for freedom. His poem of about the same time, "In Memory of Rupert Brooke," recalls the death "to make men free" of the well-known English poet and soldier.

Kilmer was, however, also critical of the English for their oppression of the Irish, especially their execution of the poet Patrick Pearse and others for their involvement in the Easter Rising of 1916. Nevertheless, soon after the U. S. declared war on Germany in April 1917, Kilmer enlisted and soon got himself transferred to New York City's "Fighting 69th" infantry regiment, whose men were overwhelmingly Irish-American and Catholic. (Kilmer himself was predominately of English background, but identified more with the Catholic Irish.)

Kilmer and his unit left for France in October 1917, and we get a partial glimpse of the anguish of his wife and parents in his mom's words, "I lived through the months he was in France, as mothers did in that horrible time, writing him nearly every day and sending parcels." As for the poet-soldier's actions and thoughts in France, on the battlefields and off, we get some idea from his few poems and short prose works from France, his more plentiful letters (including to his mother, wife, and two of his children), and Holliday's quotes from chaplains and others that served with him. For example, "He was worshiped by the men around him." "He was absolutely the coolest and most indifferent man in the face of danger I have ever seen."

One of his short prose pieces, "Holy Ireland," reflects the same basic decency and goodness that we see in so many of his works. It tells of a night he and a group of his fellow soldiers spent in the simple hut of a French widow--her husband killed in the war--and her three young children. "There was a gentle dignity about that plain, hard-working woman." She fixed them a fine meal, accompanied by ample wine, and they sang songs and hymns in front of a cozy fire. She was delighted that he and his fellow soldiers (Irish-American Catholics) shared her Catholic religion.

On 28 July,1918, Sgt. Kilmer led a small group of men to scout out a German machine gun placement within a French woods. A few hours later his dead body was discovered with a bullet hole through the brain.

Of the tremendous agony suffered by his family and friends, we can get some small inkling from the memoirs of his mother and his friend Robert Holliday. Although she wrote "I cannot write of that time" about the moment she received news of her son's death, she added, "I have written these Memories with no other object than to solace a sorely wounded heart." She also noted that she filled her "sleeping room" with "his pictures from six months to thirty years." Kilmer's oldest child, Kenton, later authored a loving book about his father, Memories of my Father, Joyce Kilmer (1993). And still later Kenton's daughter, Miriam, wrote about her grandfather: "Though some call him a 'great poet,' I believe it is fair to say that his work showed promise; that had he not been struck down in his prime, his talent would most likely have developed in later years into something approaching greatness."

Among the many millions of young men who lost their lives in WWI, we have looked at just two, Owen and Kilmer. But their stories help us sense (in McEwan's words) "the scale of the catastrophe in terms of feeling; all those unique and solitary deaths, all that consequent sorrow, unique and solitary too, which had no place in conferences, headlines, history, and which had quietly retired to houses, kitchens, unshared beds, and anguished memories."

One of the main problems with political leaders who go to war is their lack of imagination and empathy. In a February 1968 speechwriter Wendell Berry said: "We have been led to our present shameful behavior in Vietnam by this failure of imagination, this failure to perceive a relation between our ideals and our lives002E" Less than a year before, Martin Luther King Jr. had displayed such empathy when he stated:

All the while the [Vietnamese] people read our leaflets and received the regular promises of peace and democracy and land reform. Now they languish under our bombs and consider us, not their fellow Vietnamese, the real enemy. They move sadly and apathetically as we herd them off the land of their fathers. ... So they go, primarily women and children and the aged. They watch as we poison their water, as we kill a million acres of their crops. They must weep as the 
bulldozers roar through their areas preparing to destroy the precious trees. They wander into the hospitals with at least twenty casualties from American firepower for one Vietcong-inflicted injury. . . . They wander into the towns and see thousands of the children, homeless, without clothes, running in packs on the streets like animals. They see the children degraded by our soldiers as they beg for food. They see the children selling their sisters to our soldiers, soliciting for their mothers.

But even if the 1914 European leaders failed to imagine all the suffering they might cause soldiers and civilians on both sides of the conflict in WWI--and none of them even came close--one might think that they could better imagine what might happen to themselves. The monarchs of Germany, Russia, and Austria-Hungary all lost their thrones, and the Russian tsar and his family eventually lost their lives as the Communists under Lenin prevailed in a civil war. The Austro-Hungarian Empire disintegrated into separate nations, and Germany and Russia both lost territory. Historian Niall Ferguson states that "twentieth-century violence. ... was in large measure a consequence of the decline and fall of the large multi-ethnic empires that had dominated the world in 1900." The Austro-Hungarian and Russian empires, entering WWI on opposite sides, were two of them, and the Ottoman Turkish Empire, allied with Germany and Austria-Hungary, was another.

How about the victorious powers? Did the war make the "world . . s safe for democracy," as U. S. President Woodrow Wilson hoped it would when he asked Congress to declare war on Germany in April 1917? With Lenin and the communists assuming power in Russia; with Mussolini becoming prime minister in 1922 in Italy (one of the victorious nations); with Hitler playing upon Germans' dissatisfaction with the post-WWI treaty imposed upon them and becoming German chancellor in 1933; and with much of Europe loosing some of its best future leaders to battlefield deaths, it is difficult to argue that Wilson's hope was fulfilled.

Moreover, Europe as a whole was weakened financially and politically, and so too, eventually, were their imperial powers in the rest of the world. True, France regained the lost provinces of Alsace and Lorraine, but was it worth the lives they lost--for example, three out of every ten French men between the ages of eighteen and twenty-eight?

\section{AUTHOR'S BIOGRAPHY}

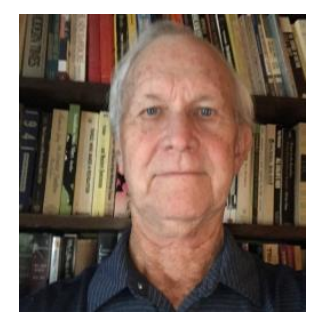

Walter G. Moss, is a professor emeritus of history at Eastern Michigan University. He has authored three books for Anthem Press: Russia in the Age of Alexander II, Tolstoy and Dostoevsky (2002); A History of Russia. 2d ed. Vol. 1 (2003) and Vol. 2 (2005); and An Age of Progress? Clashing Twentieth-Century Global Forces (2008). He is also the co-author/editor of two McGraw-Hill books: The Twentieth Century: Readings in Global History (1999) and many editions of a 20th c. global history, e.g., The Twentieth Century and Beyond: A Global History 7th ed. (2007). His most recent book is In the Face of Fear: On Laughing All the Way Toward Wisdom (Wood Lake Publishing, 2019). He is also the author of more than 300 essays and reviews since 2008 (see here) and a contributing author/editor for the History News Network.

Citation: Walter G. Moss. "A Memorial Day Lament for Capt. Wilfred Owen, Sgt. Joyce Kilmer, And all the Others Who Shouldn't Have Died in Foolish Wars" International Journal of History and Cultural Studies (IJHCS). vol 6, no. 2, 2020, pp. 21-26. doi: http://dx.doi.org/10.20431/2454-7654.0602003.

Copyright: (C) 2020 Authors. This is an open-access article distributed under the terms of the Creative Commons Attribution License, which permits unrestricted use, distribution, and reproduction in any medium, provided the original author and source are credited. 